\title{
The Correlation between Smoking Status and BMI with the MSDs Complaints of Palm Farmers
}

\author{
Husda Oktaviannoor ${ }^{1}$, Zairin Noor Helmi ${ }^{2}$, Ratna Setyaningrum ${ }^{3}$ \\ ${ }^{1}$ Public Health Studies Program, Medical Faculty of Lambung Mangkurat University, Indonesia \\ ${ }^{2}$ Orthopaedics and Traumatology Department of Ulin Regional Public Hospital, \\ Medical Faculty of Lambung Mangkurat University, Indonesia \\ ${ }^{3}$ Occupational Health and Safety Department of Public Health Studies Program Medical \\ Faculty of Lambung Mangkurat University, Indonesia
}

\begin{tabular}{l} 
Article Info \\
\hline Article history: \\
Received Apr 17, \\
Revised May 20, \\
Accepted May 29, \\
\hline Keyword: \\
BMI \\
MSDs Complaints \\
Palm Farmers \\
Smoking Status
\end{tabular}

Smoking Status

\begin{abstract}
According a study by Research Centre and Health Ecology Development Ministry of Health in 2004, palm farmers are one of a group worker that suffers complaint musculoskeletal disorder. This research to determine the correlation between the smoking status and BMI with complaints of musculoskeletal disorders (MSDS) of palm farmers in PT. X. The method are analytic observational with the cross-sectional approach. Instruments such as questionnaires, mikrotoise, scales underfoot, check the NBM, and VAS. Research technique is use purposive sampling. Research sample of 40 respondents. Results showed $32.5 \%$ light smokers, $45 \%$ moderate smokers, and $15 \%$ of heavy smokers, $17.5 \%$ weight and $2.5 \%$ obese, and $60 \%$ had complaints of MSDs. Spearman test results, it is known there is a correlation between the smoking status with complaints of MSDs ( $p=0.037$ ), there was no significant correlation between BMI with complaints of MSDs $(p=0.272)$. It can be concluded that there is a correlation between the smoking status with MSDs complaints, but there is no correlation between the BMI with the MSDs complaints. This research is expected to be input for the company to conduct training exercises ergonomics and providing information about the importance of maintaining the health of tobacco consumption.
\end{abstract}

Copyright (C) 2015 Institute of Advanced Engineering and Science. All rights reserved.

\section{Corresponding Author:}

Husda Oktaviannoor,

Public Health Studies Program,

Lambung Mangkurat University,

A. Yani Km. 36 Road, Banjarbaru City, Indonesia 70711.

Email: husda.oktaviannoor@gmail.com

\section{INTRODUCTION}

Health is an important element to be able to enjoy a quality of life, either at home or at work [1]. Occupational health is a free conditon from physical disturbance, mental, or emotional pain caused by the work place [2]. Occupational health includes harmonization of various efforts between the workers with a job and workplace both physical and psychological. One of them is aimed to prevent the onset of health problems of workers due to situation or conditions of the workplace [3].

One of the health problems are complaints of musculoskeletal disorders (MSDs). From data of the National Health Survey 2001, MSDs is one of ten most complained diseases by the community [4]. Meanwhile data of Health Department North Sumatra Provincial in 2008 mentions that MSDs ranks first of the 10 non-communicable diseases were reported from all health centers in North Sumatra with the prevalence of 12\% [5]. According Verbeek JH et al. (2011) in Abdillah (2013) about the complaints of MSDs were one of them researched in America in 2004, claimed that about $60 \%$ the manual handling workers suffered pains and injuries in the back area while working, such as lift, pull and hold something [6]. 
According to a study by Research Centre and Health Ecology Development Ministry of Health in 2004 in Yuliani et al. (2012) showed complaints of MSDs experienced by 31.6\% of palm farmers in Riau [7]. The agricultural sector especially sub-sector plantation was the one element that gets top priority in development activities of economical industry in addition to the oil and natural gas from commodity mainstay of Indonesian. The product of palm oils growing rapidly along with the development of technology and food industry as well as non-food materials for industrial [8]. Palm farmers play an important role in the food production for the countryside and urban population and remain a main source of income, employment, and export commodities [9]. Harvesting job on palm farmer allow the complaint of MSDs [10].

PT. $X$ is one of the palms oil plantation company located in South Kalimantan with the extensive whole of the gardens core is 3.406 hectares, divided into four gardens core section. Based on the data obtained, the productivity in the garden section I-IV in 2012 to 2013 has decreased from 104.370 tons to be 83.788 tons. Gardens section I experienced the largest decline difference in is $33.2 \%$ (6.822 tons) compared with the garden section II, decrease of $30.1 \%$ (6191 tons), garden section III of $23.6 \%$ (4.863 tons), and garden section IV of $13.1 \%$ (2.706 tons). The decline in productivity is one of the impacts from complaint of MSDs. Moreover, the burden on farmers to collect fresh fruit bunches at least 2.5 tons a day increase the risk the complaint.

World Health Organization (WHO) in Wijaya (2011) define the MSDs is the disturbance of the muscles, tendons, joints, vertebrae, peripheral nerves, and vascular system occur suddenly or gradually and acute and chronic [11]. Adverse impact of the disturbance will result in reduced skills to carry out the work, reduced work productivity, and increased health care costs. MSDs have three factors, namely occupational factors, environmental factors and individual factors [12]. Nurhikmah (2011) mentions the correlation between individual factors with complaints of MSDs [13].

The correlation of BMI with the complaints of MSDs is reinforced by the Winner et al. (1994) in Zahir (2012) claimed that for patients who are obese have a 2.5 times higher risk compared with thin. A person who is overweight has greater risk of low back pain, because the burden on the joints weight leverage will increase [14]. The correlation of smoking status with the complaints of MSDs is also reinforced by the McPartland et al. (1997) in Mutiah et al. (2013) mentions that the nicotine in cigarettes will increase plasma epinephrine; it causes a reduction in bone mineral content, causing the pain due to cracks or damage to the bone [15].

Based on the background above, it is necessary to do research about correlation between smoking status and BMI with MSDs complaints on palm farmers in PT. X.

\section{RESEARCH METHOD}

Design of this research was an observational analytic with cross sectional approach. The sampling technique that used in this research is purposive sampling. From the population of 47 respondents, there are 7 people that did not fulfill the inclusion criteria of the respondents did not have a history of diseases such as broken or dislocated bones, diabetes, and disturbance of the thyroid gland, at the time the research was as palm farmers, and willing to be the respondent, so that samples taken in this research are 40 samples. Data were obtained with the filling out the questionnaire to find out the identity of the respondents including smoking status and BMI as well as check the Nordic Body Map that has been standardized to measure complaints of MSDs. The independent variable in this research was smoking status and BMI. The dependent variable in this research was complaints of MSDs. Data were analyzed using univariate analysis to determine the frequency distribution of each variable separately. Meanwhile the bivariate analysis is used to analyze the correlation between the smoking status and BMI with the complaints of MSDs were analyzed using Spearman Rank with the degree of confidence is $95 \%$.

\section{RESULTS AND ANALYSIS}

\subsection{Univariate Analysis}

The focus of the research are smoking status, BMI, and complaints of MSDs on palm farmers in the PT. X. Overview of smoking status, BMI, and complaint of MSDs of respondents are showed in Table 1. 
Table 1. Distribution and Frequency of Smoking Status, BMI, and Complaints of MSDs of Palm Farmers in PT. X

\begin{tabular}{|c|c|c|}
\hline Variable & Quantity & Percentage (\%) \\
\hline \multicolumn{3}{|l|}{ Smoking Status } \\
\hline Non-Smoker (never smoked) & 3 & 7.5 \\
\hline Light smokers (<10 cigarettes per day) & 13 & 32.5 \\
\hline Moderate smokers (10-20 cigarettes per day) & 18 & 45 \\
\hline Heavy smokers (> 20 cigarettes per day) & 6 & 15 \\
\hline \multicolumn{3}{|l|}{ BMI } \\
\hline Thin $\left(<18 \mathrm{~kg} / \mathrm{m}^{2}\right)$ & 3 & 7.5 \\
\hline Normal $\left(18-24 \mathrm{~kg} / \mathrm{m}^{2}\right)$ & 30 & 75 \\
\hline Weight $\left(25-30 \mathrm{~kg} / \mathrm{m}^{2}\right)$ & 6 & 15 \\
\hline Obese $\left(>30 \mathrm{~kg} / \mathrm{m}^{2}\right)$ & 1 & 2.5 \\
\hline \multicolumn{3}{|l|}{ Complaints of MSDs } \\
\hline Yes & 24 & 60 \\
\hline No & 16 & 40 \\
\hline Total & 40 & 100 \\
\hline
\end{tabular}

Source: Primary Data

Table 1 shows the distribution and frequency of smoking status of the 40 respondents that selected as samples in this research. The average respondents smoked 10.08 cigarettes per day. Of the 40 respondents there were 3 (7.5\%) of respondents non-smokers, 13 (32.5\%) light smokers, 18 (45\%) moderate smokers, and $6(15 \%)$ heavy smokers. The average BMI of the respondents are $21.581 \mathrm{~kg} / \mathrm{m}^{2}$. Of the 40 respondents there were $3(7.5 \%)$ of respondents thin, 30 people (75\%) of normal, 6 people (15\%) weight, and 1 (2.5\%) obese. Most of the respondents as many as 24 (60\%) of respondents have complaints of MSDs. While as many as 16 (40\%) of respondents did not have complaints of MSDs.

\subsection{Bivariate Analysis}

The results of the analysis of the correlation between smoking status and BMI with the complaints of MSDs on the respondents by using the Spearman Rank Correlation test can be seen in Table 2.

Table 2. Analysis of the Correlation between Smoking Status and BMI with the Complaint of MSDs

\begin{tabular}{lccc}
\hline \multicolumn{1}{c}{ Variable } & P-value & Correlation Spearman & Evidence \\
\hline $\begin{array}{l}\text { The correlation of smoking status with the } \\
\text { complaints of MSDs }\end{array}$ & 0.037 & 0.332 & Correlation \\
$\begin{array}{l}\text { The correlation of the BMI with the complaints } \\
\text { of MSDs }\end{array}$ & 0.272 & -0.178 & No correlation \\
\hline
\end{tabular}

Table 2 shows that variables between smoking status with complaints of MSDs there is a correlation with $\mathrm{p}$-value $=0.037(\mathrm{p}<0.05)$ with correlation coefficient 0.332 , indicating a positive correlation with the strength of the moderate correlation. Based on the interviews with the palm farmers, most of the respondents were smokers with smoking status variety is 13 persons (32.5\%) light smokers, 18 people (45\%) moderate smokers, and 6 (15\%) heavy smokers. According Rahayu (2012), that smoking positively is linked with complaints of MSDs such as back pain, sciatica or intervertebral dischemia [16].

Smokers are more likely to suffer back problems than non-smokers. The longer and higher frequency of smoking, be higher as well the level of perceived complaints. It is caused by smoking can damage muscle tissue and reduce nerve response to pain. Cause smokers feel more complaints of MSDs include nicotine is the powerful stimulant to inflict pain on the body's response and cigarette smoke causes immune damage to the muscle and bone tissue thereby reducing the blood supply to the tissues, increases blood clots or reduce the flow of nutrients to the muscles and joints [13],[17]. The smoking effects also still settle in the body of someone that had stopped smoking. This is in accordance with the opinion of Palmer et al in Anisa (2013) that claimed that there is a significant correlation between the smoking status with the pain of musculoskeletal in smokers and ex-smokers [15].

This research in line with the research by Santiasih (2013), about the study of manual material handling against of low back pain on the textile workers declare that there is a correlation between smoking and complaints of MSDs with p-value of 0.017 ( $\mathrm{p}<0.05)$ [18]. In line with Santiasih, research Andreani, et al (2013) about the job attitudes correlated with subjective complaints of tailors on Patua Surabaya street declared that there is a correlation between the smoking status with subjective complaints with p-value of $0.036(\mathrm{p}<0.05)$ [19].

IJPHS Vol. 4, No. 2, June 2015 : $140-144$ 
Variables between the BMI with the complaints of MSDs there was no correlation with p-value = $0.272(\mathrm{p}>0.05)$ with a correlation coefficient -0.178 , indicating a negative correlation with the strength of that correlation is very weak. According to the theory that the larger the a person's BMI, the greater the influence on the complaints of MSDs. But in reality on the ground shows that the normal BMI was experiencing the same thing that there are complaints of MSDs. Based on the research carried out, the average palm farmers have normal nutritional status that is equal to $21.581 \mathrm{~kg} / \mathrm{m}^{2}$. Availability of good nutritional status in the body greatly affects the level of the physical fitness of a worker.

BMI is a factor that can cause complaints of MSDs [20]. In people that have excessive weight the risk of low back pain is greater, because the burden on the joints weight leverage will increase, so as to allow the occurrence of low back pain. Skeletal muscle complaints related to body size over due to the equilibrium structure in skeletal to receive the load, good weight of the body as well as other additional loads [14].

Results of this research are not in line with research carried out by Septiawan (2013) about the factors related low back pain in workers building the PT. Mikroland Semarang claimed that there is a correlate between the BMI with complaints of MSDs with p-value of $0.030(p<0.05)$ [21]. However, in line with research carried out by Isnain (2013) on the correlated between the BMI and high heels with complaints of lower back pain in the sales promotion girl (SPG) Salatiga Ramayana claimed that there is no correlation between the BMI with lower back pain complaints with the p-value is 0.345 ( $>>0.05$ ) [22]. In line with research Isnain, research Polii, et al (2013) also claimed that there was no cerrelation between the nutritional status and musculoskeletal complaints with p-value of $0.054(\mathrm{p}<0.05)$ [23].

\section{CONCLUSION}

Palm farmers were 3 (7.5\%) of respondents non-smokers, 13 (32.5\%) light smokers, 18 (45\%) moderate smokers, and 6 (15\%) heavy smokers. Palm farmers were $3(7.5 \%)$ of respondents thin, 30 people (75\%) of normal, 6 people (15\%) weight, and 1 (2.5\%) obese. Most of the respondents as many as $24(60 \%)$ of respondents have complaints of MSDs. While as many as 16 (40\%) of respondents did not have complaints of MSDs. There is a correlation between the smoking statuses with complaints of MSDs on palm farmers in PT.X. There was no correlation between the BMI with complaints of MSDs on palm farmers in PT.X. Next research are expected to researching other variables of environmental factors (temperature and humidity) and work (working frequency, work posture, duration, and workload) with complaints of MSDs as well as complement the limitations contained in this research. The company is expected to provide training to palm farmers in the form of stretching and gymnastics movement's ergonomics to reduce the incidence of MSDs that can increase work productivity. Provision of information to farmers about the importance of maintaining healthy oil on cigarette consumption especially the influence of the muscular and skeletal complaints perceived that due to tobacco consumption can be reduced.

\section{ACKNOWLEDGEMENTS}

Thanks to Allah SWT for the gift that has been given. Thanks to all stakeholders who support the passage of this research.

\section{REFERENCES}

[1] Suaeb A., "Occupational health and safety (case study: cleaning windscreens)”, Jakarta Universitas Gunadarma, (http://www.gunadarma.ac.id/library/articles/graduate/.../Artikel_30403013.pdf, accessed on 25 September 2013).

[2] Sholihah Q., Anward HH., “Textbook ergonomics and human factors (basic concepts)”, First edition. Banjarmasin, P3A1 Lambung Mangkurat University in cooperation with Nusa Media Bandung, 2012.

[3] Buchari, "The management of occupational health and personal protective equipment", Medan: Sumatera Utara University, 2007.

[4] National Health Survey, "Report of SKRT 2001: Morbidity and disability studies”, Jakarta: Balitbangkes Depkes RI, 2002.

[5] Health Department of North Sumatra Province, "Health profile of North Sumatra Province", 2008. (http://www.depkes.go. id/downloads/ profil/ prov/ sumu/202008.pdf, accessed on 27 March 2014).

[6] Abdillah F., "Working posture analysis with method rapid upper limb assesment (RULA) of porter fruit workers in an "Agen Ridho Ilahi" Johar market Semarang”, Public Health Journal, vol/issue: 2(1), 2013.

[7] Yuliani S., Ekawati, Hanifa MD., "Analysis of the risk level of ergonomics and complaint of musculoskeletal disorders in women stone crushers", Proceedings of the National Seminar in Order Anniversary Diponegoro University 55 "World fit for children”, Semarang: Publisher Agency Diponegoro University, 2012.

[8] Mursidah, "Optimization of oil palm farm income”, Productivity of Agricultural Economics, vol/issue: 6(2), pp. 915, 2009. 
[9] Olowogbon ST., Fakayode SB., "Commercializing agriculture in Africa: the environtmental health and safety implications and the way forward", Invited paper presented ath the $4^{\text {th }}$ Internasional conference of the African Association of Agricultural Economists. Tunisia, 2013.

[10] Ng Yee G., et al., "Ergonomics observation: harvesting task oil palm plantation”, Journal of Occupational Health, vol. 55, pp. 405-414, 2013.

[11] Wijaya AT., et al., "The relation between risk factors and musculoskeletal impairment in dental students: a preliminary study”, Journal of Dentistry Indonesia, vol/issue: 18(2), pp. 33-37, 2011.

[12] Bukhori E., "The correlation between the risk of a job with the occurrence of musculoskeletal complaints disorders (MSDs) at the movers load of gold miners in the district of Lebak regency Cilograng in 2010”, Skripsi, Jakarta, Faculty of Medicine and Health Sciences Syarif Hidayatullah State Islamic University, 2010.

[13] Nurhikmah, "Factors correlated with musculoskeletal disorders (MSDs) on the workers of in District Benda Tangerang City in 2011”, Skripsi, Jakarta, Syarif Hidayatullah State Islamic University, 2011.

[14] Zhahir HQA., "Overview risk factors for musculoskeletal disorders (MSDs) on employees at head office of PT. X Jakarta in 2012”, Skripsi, Depok: Public Health Faculty Indonesia University, 2012.

[15] Mutiah A., Setyaningsih Y., Jayanti S., "Analysis of the level of risk of musculoskeletal disorders (MSDs) with The BRIEF $^{\mathrm{TM}}$ surveys and individual characteristics of the complaint MSDs wok makers in the village Cepogo Boyolali”, Public Health Journal, vol/issue: 2(2), 2013.

[16] Rahayu WA., "Factors related with musculoskeletal disorders in lift-haul workers of quarry industry in District Karangnongko Klaten”, Semarang: Public Health Faculty Diponegoro University, 2012.

[17] Aprilia M, "Overview of ergonomic risk factors related complaints of musculoskeletal disorders (MSDs) in the construction workers of PT. Wasktia Karya in recreation and sports facilities project boker Ciracas in 2009”, Skripsi, Depok: Public Health Faculty Indonesia University, 2009.

[18] Santiasih I., "The study of manual material handling on the incidence of low back pain in the textile workers", J@TI Undip. Shipbuilding Polytechnic Surabaya State, vol/issue: 8(1), 2013.

[19] Andreani MUD., Paskarini I., "Work attitude-related complaints in the Road Patua tailor Surabaya", Journal of Health Promotion Airlangga University, vol/issue: 1(2), pp. 201-208, 2013.

[20] Dewi NKN., Kerta IMD., "Complaints of muskulsokeletal on sales promotion girl (SPG) high heel shoe wearer Mall in Denpasar in 2012”, Research Article Community Health, vol/issue: 1(2), pp. 143-150, 2012.

[21] Arovah NI., “The basics of physiotherapy in sports injuries”, Yogyakarta, 2010.

[22] Isnain M., "The correlation between high heels and body mass index (BMI) with complaints of lower back pain in the sales promotion girl (SPG) Ramayana Salatiga”, Public Health Journal, vol/issue: 2(1), 2013.

[23] Polii FJ., Joseph WBS., Rumampuk J., "The correlation between age, periode of working, and nutritional status with complaints of musculoskeletal disorders in workers unloading in the port of Manado", Research. Manado: Public Health Faculty Sam Ratulangi University, 2013. 